\title{
Marble from Neolithic quarries at the Bílý Kámen Hill near Sázava (Czech Republic) and its petrographic-geochemical characterization
}

\author{
Antonín PŘICHYSTAL ${ }^{1}$, Pavel BURGERT ${ }^{2, *}$ and Petr GADAS ${ }^{1}$ \\ 1 Masaryk University, Department of Geological Sciences, Kotlářská 2, 61137 Brno, Czech Republic \\ 2 Czech Academy of Sciences, Institute of Archaeology, Prague, v.v.i., Letenská 4, 11801 Prague 1, Czech Republic
}

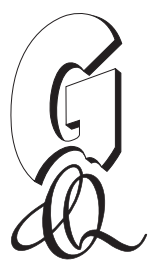

Přichystal, A., Burgert, P., Gadas, P., 2019. Marble from Neolithic quarries at the Bílý Kámen Hill near Sázava (Czech Republic) and its petrographic-geochemical characterization. Geological Quarterly, 63 (4): 811-821, doi: 10.7306/gq.1503

Associate Editor: Tomasz Bajda

The longest known prehistoric quarries for non-siliceous (non-flint) rocks in continental Europe were discovered on the Bíly Kámen Hill in central Bohemia (Czech Republic) already in the period between the World Wars. Due to post-war events, this has been all but forgotten, and awareness of this important locality still exists only in the local research community. Its research potential has not yet been exhausted. The article presents the first exact mineralogical and geochemical characteristics of the raw material extracted in these prehistoric quarries. The raw material is fundamentally different from some of the marble artefacts from nearby workshops. The aim of this research is to create a solid foundation for the future detailed study of prehistoric artefacts made from marble and to review the deep-rooted idea of their distribution within the oldest agricultural communities in Central Europe.

Key words: Prehistoric mining, marble, Neolithic, Bílý Kámen, Bohemia, petroarchaeology.

INTRODUCTION

The Bílý Kámen (White Stone) Hill is located near the town of Sázava, $\sim 40 \mathrm{~km}$ south-east of Prague (Fig. 1). The history of the discovery of the site began in 1937 and it is associated with local researcher Ladislav Trčka. He found the first traces of prehistoric polished industry in the top part of an active marble quarry. This discovery was followed in the autumn of the same year by the work of geologist Karel Žebera (1911-1986), who conducted small-scale archaeological research of two archaeological features there. Žebera (1939) interpreted one of these as a prehistoric mining pit. In the middle of the pit, he found a layer of marble grit containing up to $5 \mathrm{~cm}$ large fragments of marble and, above all, parts of the broken hammer axes. Based on their presence, he dated the site to the Neolithic period (Žebera, 1939). It was the first finding of prehistoric mining of non-flint rocks on the European continent.

The documentation of this research has been preserved only fragmentarily (Fig. 2). Several important facts can be reconstructed, however. The remains of the Neolithic quarry were preserved between two medieval features that were filled with a mixture of Neolithic artefacts (fragments of polished tools, a flint

\footnotetext{
* Corresponding author, e-mail: burgert@arup.cas.cz

Received: February 1, 2018; accepted: September 27, 2019; first published online: December 16, 2019
}

arrowhead, a sherd of Neolithic pottery) and items from the medieval period (pottery from the 15th and 16th centuries, iron tools, an item made of lead). Archaeological work continued in 1939 with the investigation of two more mining pits. In total, over 6,000 pieces of polished industry were acquired during that time. The assemblage of tools from the site contains only a small number of whole tools; most of it consists of their fragments (Žebera, 1955). The author of the research considered them mining tools that were broken during mining and classified them as hammers and hammer-axes made of amphibolite from the surrounding area. They are represented predominantly by broken perforated hammer-axes (Fig. 3). This does not correspond to mining tools from other places of prehistoric exploitation of stone raw materials (e.g., those used during the extraction of metabasite in the Jizera Mountains). There are relatively large and heavy hammer-stones that are rounded on one side and pointed on the other and are made from local metabasite (Šída et al., 2014). Another suggestion in the literature (Vencl, 1960: 6), based on their morphological analysis, is that the huge collection of fragments of polished industry in the quarries on the Bílý Kámen Hill had been brought from Neolithic settlements at various distances from the site already in broken condition and were used secondarily there.

The Bílý Kámen Hill (456 m a.s.I.) represents part of the Kácov Hills that are cut by a deep valley of the Sázava River (Fig. 4A). In modern maps, the Bílý Kámen area is referred to as "Na Sedlišti". This site and its surrounding area are now covered by a forest. The elevation of the area is between $300-500 \mathrm{~m}$ a.s.l. There is no land suitable for agricultural use 


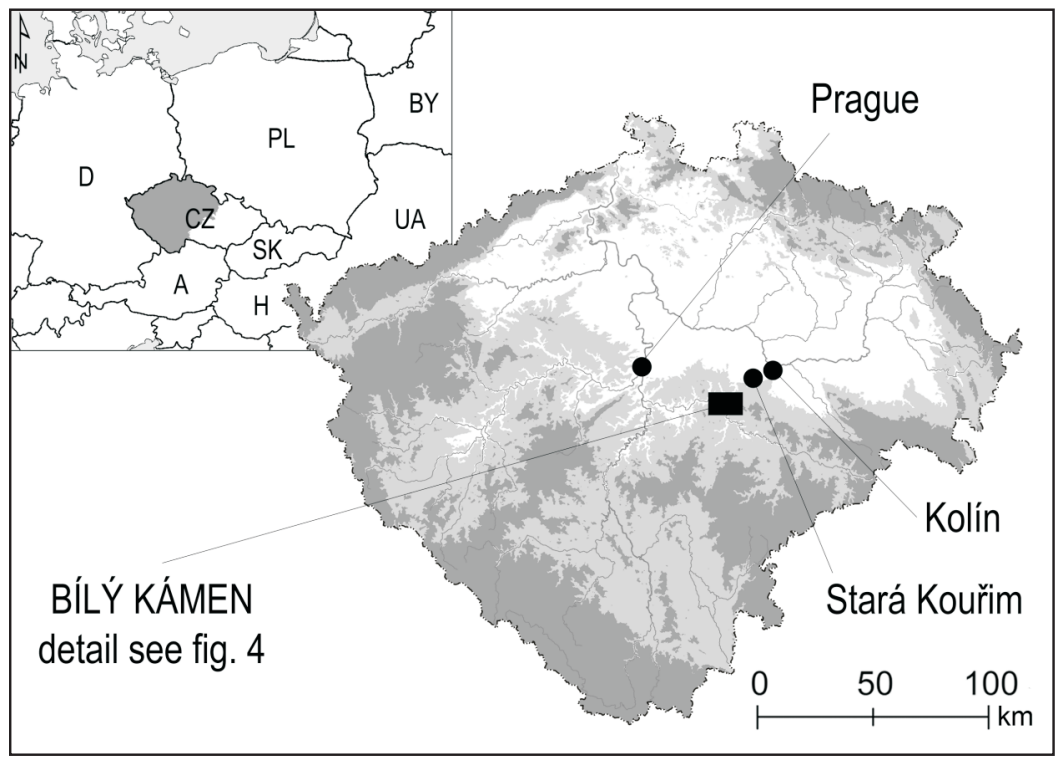

Fig. 1. Bohemia in Central Europe with the position of Prague, the study area around the town of Sázava, and other important sites mentioned in the text

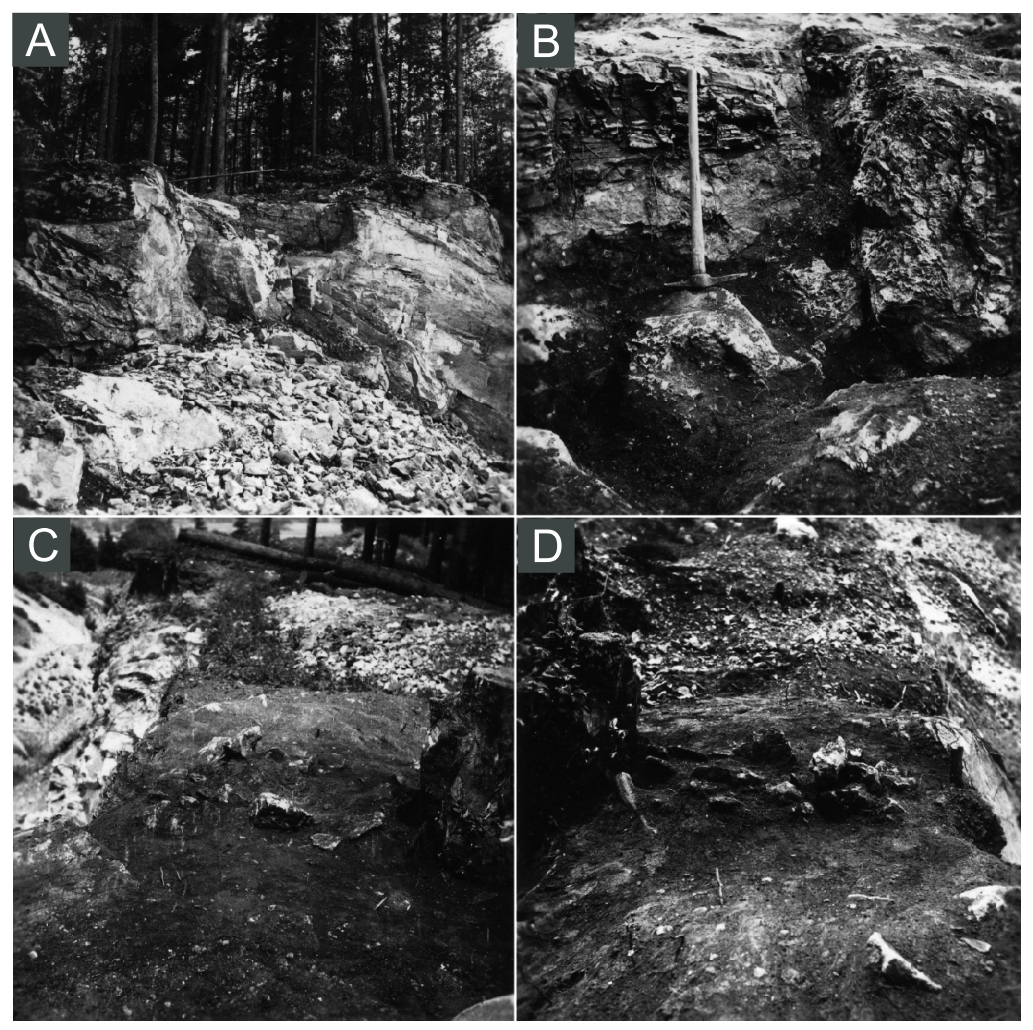

Fig. 2. A small-scale Neolithic quarry disturbed by two later medieval quarries (A-D)

The situation captured during the research of K. Žebera in 1937; without scale (photo by L. Weidermann 1940. ( ) Archive of the Institute of Archaeology of the Czech Academy of Sciences, Prague) 

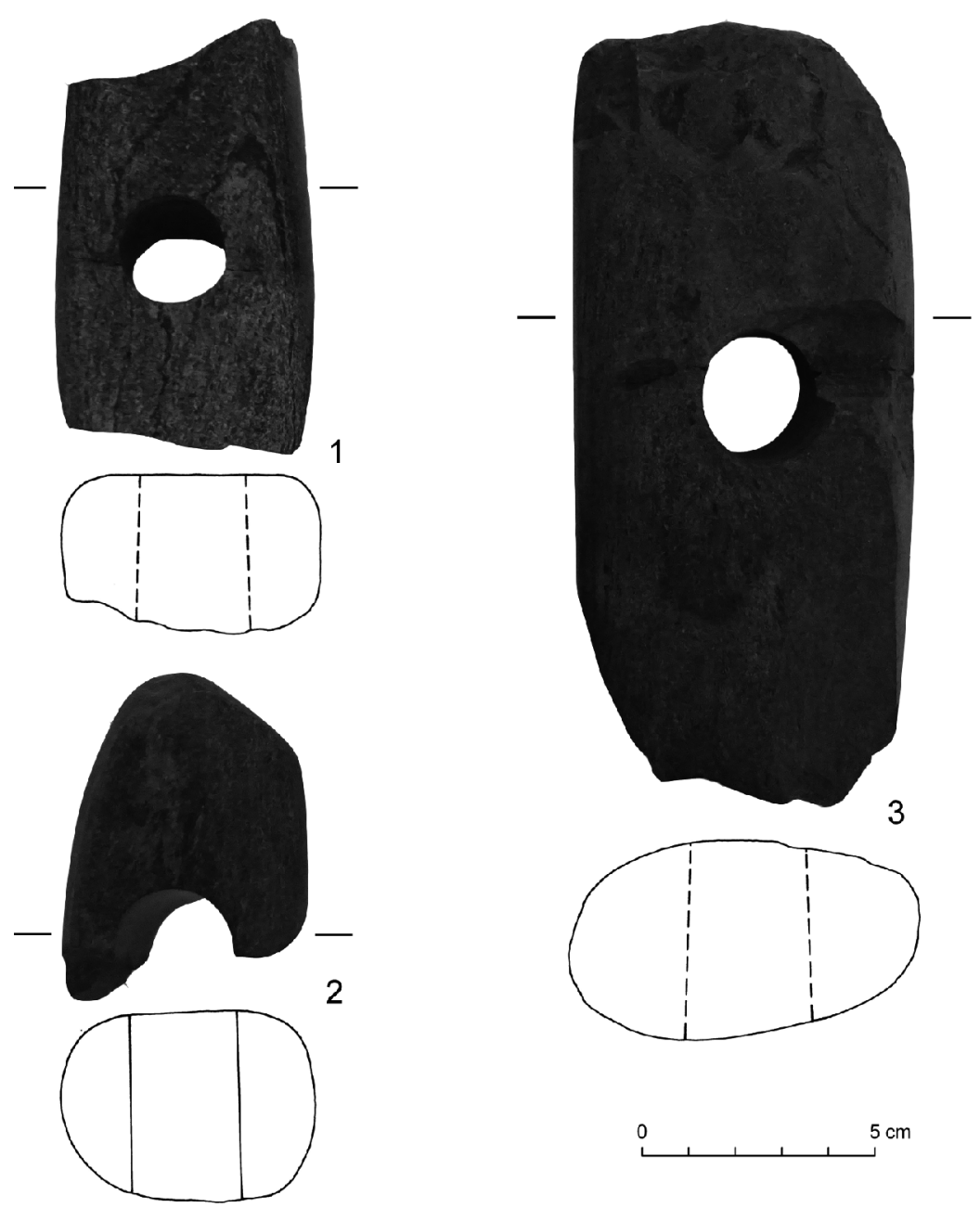

Fig. 3. The examples of characteristic tools found by Karel Žebera

1-3 hammer axes broken in a borehole (phot. by P. Burgert)

and therefore the surprising presence of Neolithic farmers here is most likely related to the extraction of stone raw material (marble).

The debate on this unique discovery was interrupted by the Second World War and then by the post-war situation in Czechoslovakia. It was not until the end of the 1960s that Slavomil Vencl (1971) from the Institute of Archaeology of the Czechoslovak Academy of Sciences in Prague decided to follow-up on Žebera's research. In the first stage, he compiled a detailed map of the whole hill, where he documented relics of 144 pits visible on the surface. These probably originated over a long period of time from the Neolithic period to the modern times. This fact, however, has not been verified by archaeological excavation.

Regarding the distribution of marble raw material, Žebera $(1939,1955)$ assumed its transport to central Bohemia to the regions of Kolín $(\sim 30 \mathrm{~km})$, Prague $(\sim 45 \mathrm{~km})$ or the area of Kladno ( 70 km), where marble bracelets or beads were found. The distribution of marble bracelets was studied in greater detail by Zápotocká (1984). She documented 24 specimens from 17 sites in central and northwestern Bohemia where they are associated with a later stage of the Stroked Pottery culture (SBK /DE Stichbandkeramik Kultur/; 4900-4500/4400 cal BC; Fig. 5B). The other territory with a significant representation of marble bracelets is the surroundings of the Saale River in central Germany (Fig. 5A), specifically at the burial grounds in Rössen near Halle, where they are associated with the Rössen culture (Niquet, 1937). Bracelet production in central Bohemia is documented only in the Kourim area ( 15 km NNE) and in Kolín area $(\sim 25-30 \mathrm{~km})$ in the form of drilling cores up to $5-6 \mathrm{~cm}$ wide and up to $9.5 \mathrm{~cm}$ high. Probably already finished products - bracelets - were transported (Fig. 5A). It can be concluded, however, that the Chaîne opératoire (operating sequences) of marble bracelets has not yet been described.

Since no other prehistoric marble quarries have yet been identified in Central Europe, archaeological literature usually assumes the origins of marble bracelets to have been on the Bílý Kámen Hill near Sázava. Despite this assumption, there is still lack of detailed characterization of the marble raw material from these prehistoric quarries in order to confirm their provenance. Until now, there has only been a classic petrographic description of the marble from the Bílý Kámen Hill, which was 


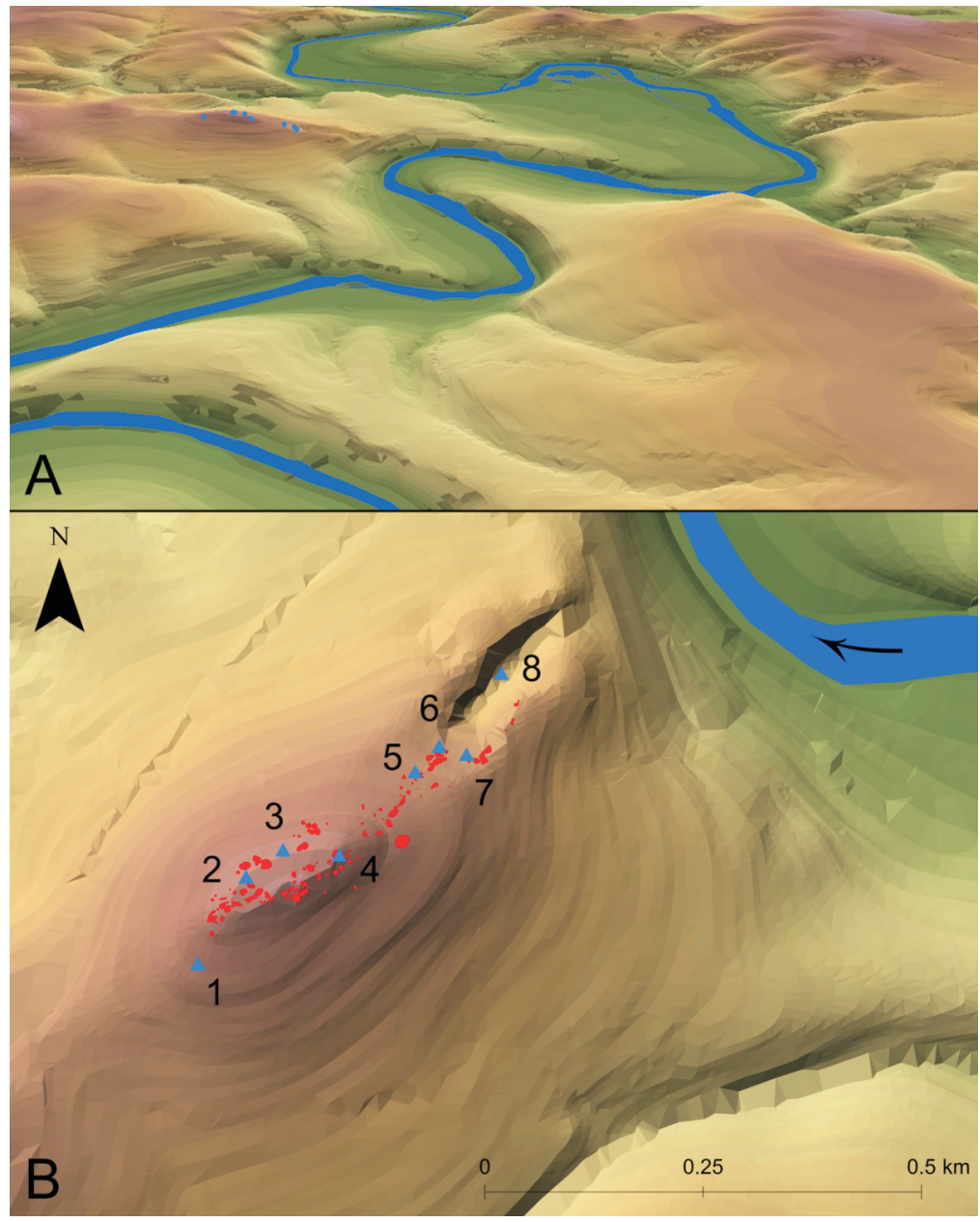

Fig. 4. Map of the Bílý Kámen Hill

A - view from the south, blue dots showing the position of the sampling sites; $\mathbf{B}$ - terrain model of the locality with marble mining pits from neolithic to modern times (red polygons) and the position of the sampling sites (blue triangles); the map modified in accordance with Vencl (1971); the same sample numbering is maintained throughout the entire work

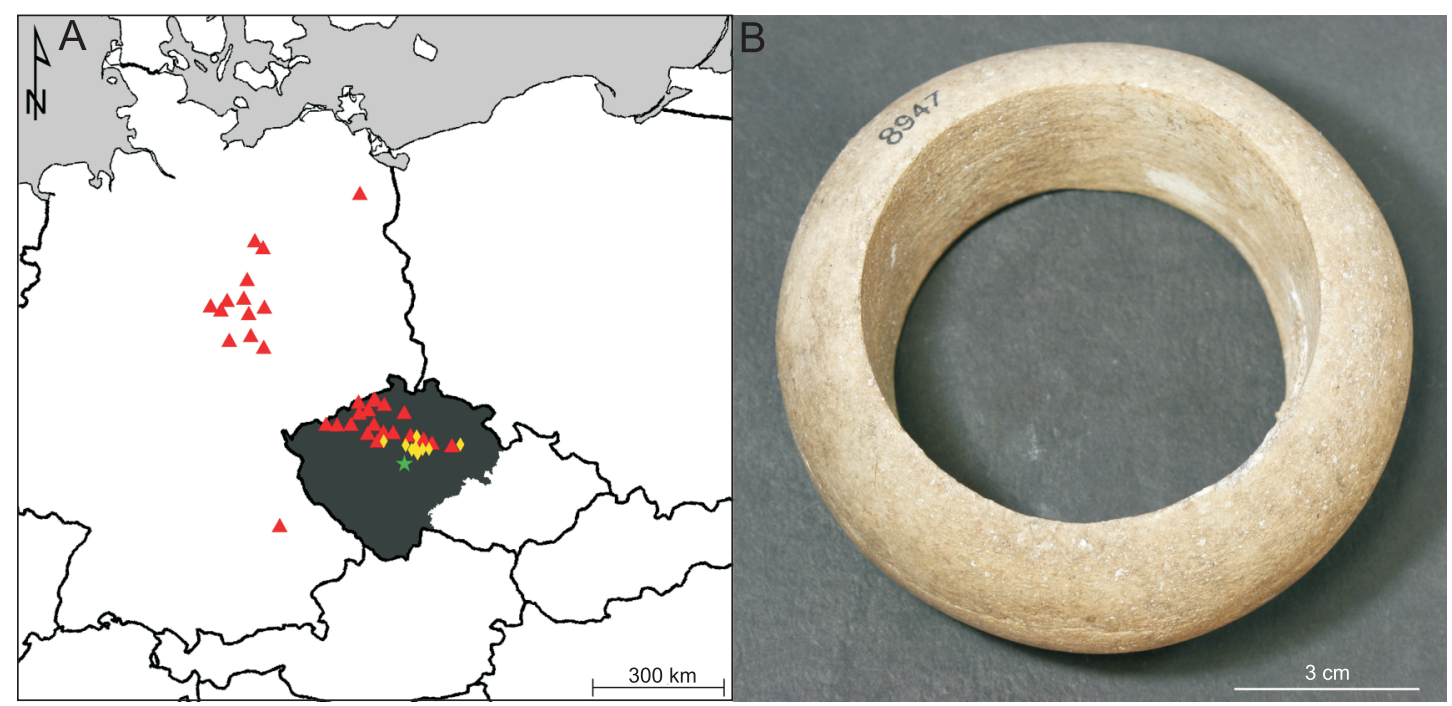

Fig. 5. Distribution of marble bracelets in Central Europe (A) and an example of a finished bracelet found in 1936 in the SBK grave in Kolín (B)

Red triangles - findings of marble bracelets, yellow diamond - findings of marble drilling cores, green asterisk - Bílý Kámen (map after Zápotocká, 1984; photo by T. Davidová) 
published in the Czech language over 80 years ago (Koutek, 1936), and is insufficient. Therefore, in this paper, we focus on the comprehensive characterization of this raw material.

\section{GEOLOGICAL BACKGROUND OF THE SITE}

The Bílý Kámen Hill is formed by an $850 \mathrm{~m}$ long and up to $200 \mathrm{~m}$ wide marble body with a NE-SW orientation, surrounded by biotite and sillimanite-biotite paragneiss (Kodym, 1997). The age of the rocks cannot be reliably documented due to their strong metamorphism. The original sediments are most likely of Lower Paleozoic age and were metamorphosed during the Variscan orogeny. From the perspective of regional geology, this is part of the Šternberk-Čáslav Group situated on the border between the Moldanubian Zone and the Kutná Hora-Svratka Unit. While formerly this group was usually classified as part of the Kutná Hora-Svratka Unit, more recently there have been frequent opinions on its classification within the Moldanubicum (Kachlík, 1999). Further to the east, mica schists or two-mica paragneisses with abundant amphibolite bodies outcrop along the Sázava River. On the other hand, just $500 \mathrm{~m}$ to the west of the Bilý Kámen Hill, there are the cataclastic two-mica or biotite granites-granodiorites that form the edge of the Central Bohemian Pluton (Fig. 6). Granite or granodiorite veins can be found not only in the immediate vicinity of the marble body, but they also penetrate into it (Koutek, 1936). The marble is also affected by a number of tectonic disturbances that occur mainly in the NNE-SSW direction (continuation of the Kourim Fault), with the second dislocation system being almost perpendicular to the first one. Particularly at the point of crossing of tectonic disturbances, the marble is crushed and therefore unsuitable for further processing.
Another smaller outcrop of crystalline limestone occurs in the middle of amphibolites in the Sázava Valley, $\sim 1.5 \mathrm{~km}$ south of the Bílý Kámen Hill (Kachlík, 1999). After $\sim 1$ km in a straight line, the river creates a valley with alternating amphibolite and dolomitic limestone between Malovidy, Český Šternberk and Soběšín. Marble from Český Šternberk contains $\mathrm{Ag}-\mathrm{Pb}-\mathrm{Zn}$ ores (Šrein et al., 2007), the presence of which has even encouraged their mining in the past. It is obvious that this dolomitic limestone could have been of interest to prehistoric prospectors, but there is no evidence of this.

\section{METHODS}

In 2017, eight samples were taken along the long axis of the marble body (Fig. 7) to identify its possible variability. Petrographic thin-sections of the rocks were studied under an Olympus $B X 5$ polarization microscope and using the CAMECA SX100 electron microprobe analyser in the Laboratory of Electron Microscopy and Microanalysis of the Masaryk University's Faculty of Science in Brno.

Measurements were carried out under the following conditions: wave propagation mode, accelerating voltage $15 \mathrm{keV}$, beam current 10 and $20 \mathrm{nA}$, beam size $2-7 \mu \mathrm{m}$. The counting times for individual elements were $20-40$ seconds and 10-20 seconds for the backgrounds. Almandine (Fe K $\alpha$ ); sanidine (AI K $\alpha, \mathrm{K} \mathrm{K} \alpha)$; albite $(\mathrm{Na} \mathrm{K} \alpha)$; barite $(\mathrm{Ba} \mathrm{K} \alpha)$; pyrope $(\mathrm{Mg} \mathrm{K} \alpha)$; wollastonite ( $\mathrm{Si}, \mathrm{Ca} \mathrm{K} \alpha)$; $\mathrm{Sn}(\mathrm{Sn} \mathrm{K} \alpha)$, columbite Ivigtut $(\mathrm{Nb} \mathrm{K} \alpha)$, spessartine (Mn K $\alpha$, Si K $\alpha)$; titanite, anatase ( $\mathrm{Ti} \mathrm{K} \alpha$, Si K $\alpha$ ); $\mathrm{CrTa}_{2} \mathrm{O}_{6}(\mathrm{Ta} \mathrm{K} \alpha)$, topaz ( $\left.\mathrm{F} \mathrm{K} \alpha\right)$; vanadinite $(\mathrm{Cl}$ $\mathrm{K} \alpha, \mathrm{V} \mathrm{K} \alpha)$; chromite $(\mathrm{Cr} \mathrm{K} \alpha)$; gahnite $(\mathrm{Zn} \mathrm{K} \alpha)$; U (U K $\alpha)$, $\mathrm{ScVO}_{4}(\mathrm{Sc} \mathrm{K} \alpha)$; brabantite (Th $\left.\mathrm{K} \alpha\right), \mathrm{Ni}_{2} \mathrm{SiO}_{4}(\mathrm{Ni} \mathrm{K} \alpha)$; fluorapatite $(\mathrm{P} \mathrm{K} \alpha) ; \mathrm{SrSO}_{4}(\mathrm{Sr} \mathrm{K} \alpha, \mathrm{S} \mathrm{K} \alpha)$; zircon $(\mathrm{Zr} \mathrm{K} \alpha)$; phosphates of the relevant REEs (La, Ce, Pr, Nd, Sm, Gd, $\mathrm{Dy}, \mathrm{Er}, \mathrm{Yb})$. The contents of the measured elements that are

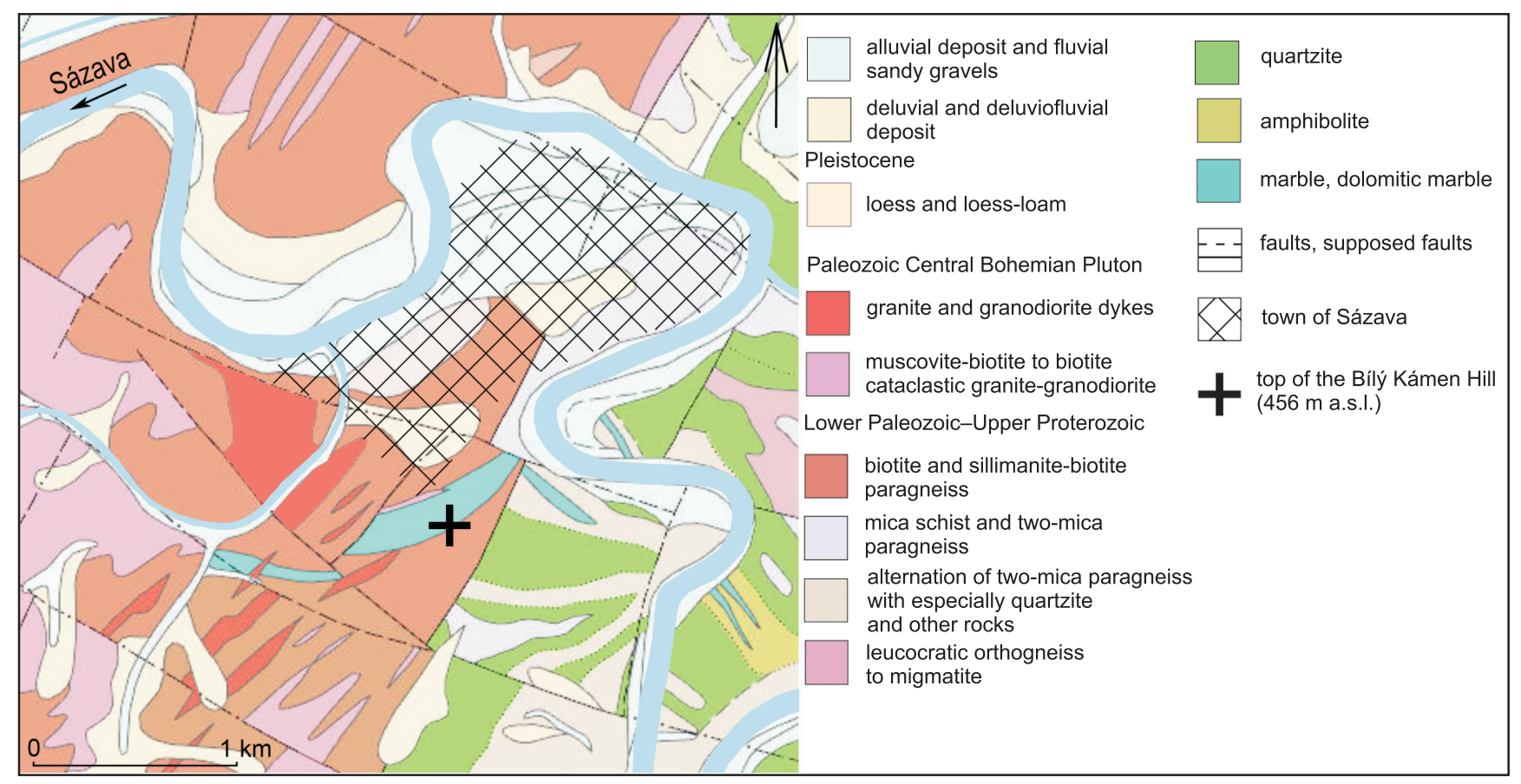

Fig. 6. Geological map of the study area, showing the occurrence of marble bodies 


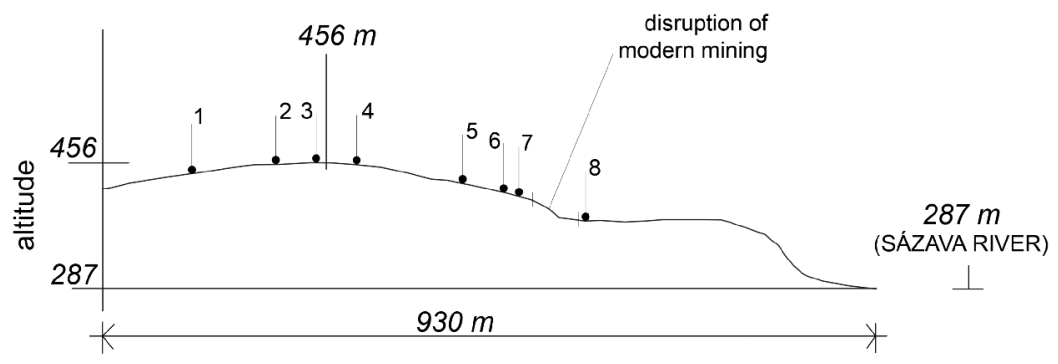

Fig. 7. Section across the Bílý Kámen Hill, showing the altitude level of the studied sample

not listed in the tables were below the detection limit of the apparatus ( 0.02-0.05 wt.\%). Raw data were corrected using the X-phi correction (Merlet, 1994).

Some of the samples were stripped of weathered parts, crushed, homogenized and sent for complete geochemical analyses to the Bureau Veritas Minerals, Vancouver, Canada. The conditions under which the analyses were carried out can be found at Bureau Veritas Metals and Minerals. We determined also densities of calcite marble from the prehistoric quarries, drilling core from Stará Kouřim and dolomitic marbles from the nearby area at Český Šternberk in our laboratory.

All mineral abbreviations in the text and figures have been taken from Whitney and Evans (2010)

\section{RESULTS OF THE PETROGRAPHIC INVESTIGATION}

Macroscopically, most samples have a sugar-white colour, some with visible grey streaks or light ochre colour in the area of smaller faults. The marble in samples 4 and 5 (central and northwestern part of the hill) has a different, distinct grey tint (very light grey N8 to light grey N7 in the Rock-Colour Chart with genuine Munsell color chips, Geological Society of America, 1995) and the rock contains several-millimetre-wide white calcite veins. The structure of the rock is massive without evident metamorphic schistosity; its texture is granoblastic, in places cataclastic (brecciated). Larger calcite grains with a diameter of $\sim 1-5 \mathrm{~mm}$ are changed in a mixture of smaller grains with various dimensions (Fig. 8). They also show a typical multiple twinning that is gooseneck-deformed in some grains. The marble is poor, with only small admixture of clastic quartz usually $<0.1 \mathrm{~mm}$ in size, and few isometric apatite grains. In sample 2017 3, signs of pressure dissolution in the form of common stylolites were identified. They are indicated by a wrinkled discontinuous string of phyllosilicate from the smectite group and apatite crystals.

\section{CARBONATES}

The microprobe analysis shows that the predominant carbonate is represented by relatively pure calcite (Fig. 9; Bílý Kámen 2017 1, 20173 and 20178 marble samples), occasionally with a slight admixture of Mg up to 0.02 apfu $(0.67 \%$ $\mathrm{MgO}$ ) and trace amounts of $\mathrm{Fe}$ and $\mathrm{Mn}$ (both elements up to $0.13 \% \mathrm{MnO}$ and $\mathrm{FeO}$ ). The different archaeological sample from Stará Kouřim 2017_10 (drilling core of a bracelet) made

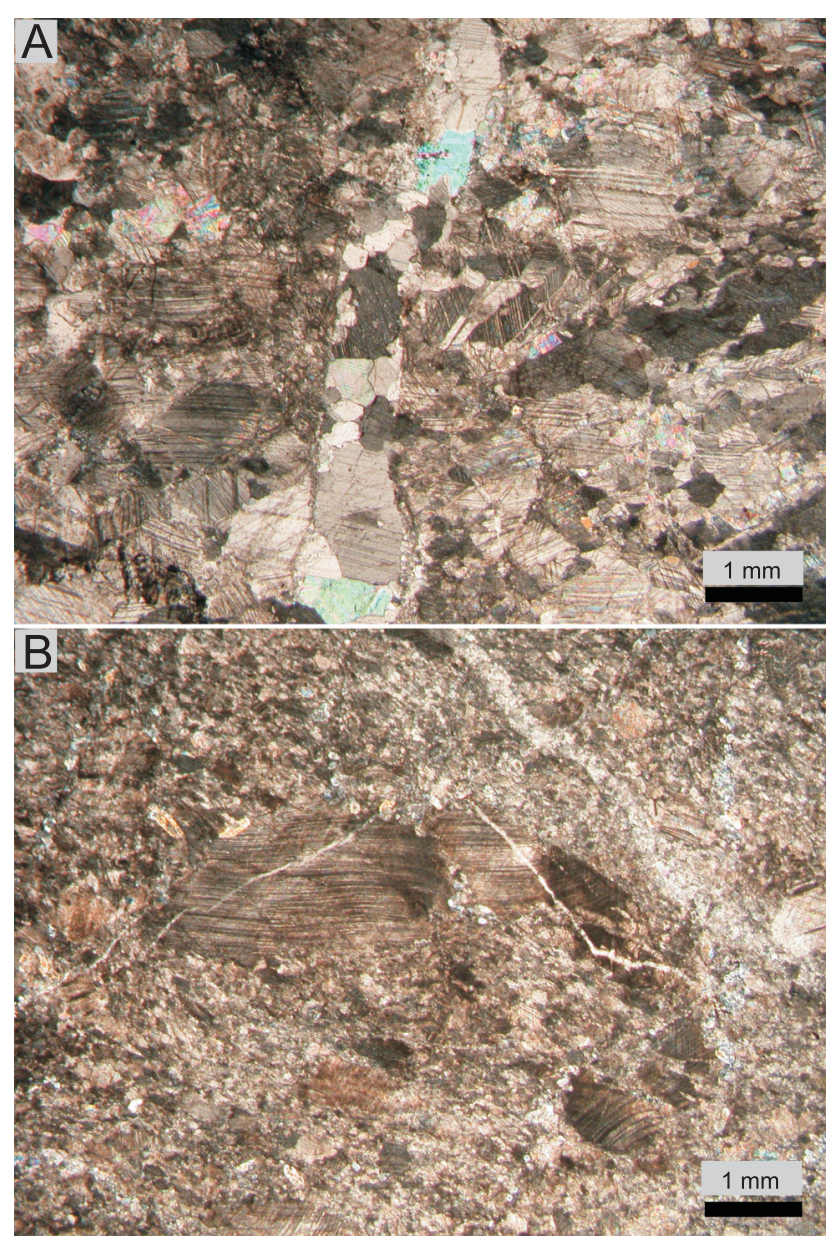

Fig. 8. Marbles from Bílý Kámen in a thin section under polarizing microscope with crossed polars

Sample 2017_3 (A) has almost non-deformed granoblastic texture while sample 2017_2 (B) shows strongly deformed texture with only large relict grains having a gooseneck-deformed multiple twinning. Younger veinlets filled by non-deformed calcite are also visible

of dolomitic marble contains both calcite with $\mathrm{Mg}$ up to 0.04 apfu (1.65 wt. \% MgO) without additional admixtures, and dolomite with traces of $\mathrm{Mn}$ and $\mathrm{Fe}$ (up to 0.11 or $0.27 \mathrm{wt} . \%$ oxides; Fig. 12B, C). No other elements have been found in the carbonates. 


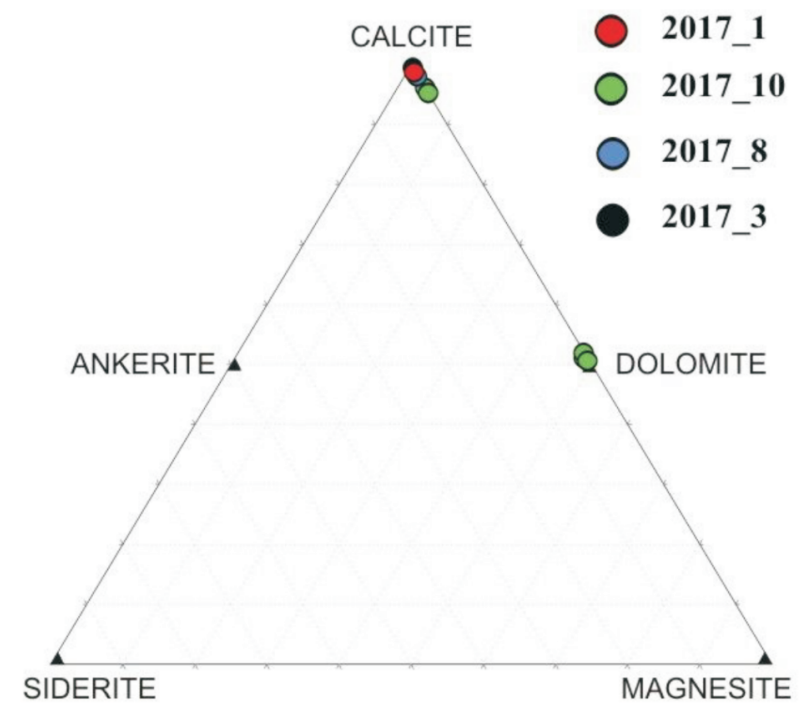

Fig. 9. Carbonates of marble samples from the Bílý Kámen Hill and of archaeological artefact from Stará Kouřim (2017_10) in the Ca-Mg-Fe classification triangle
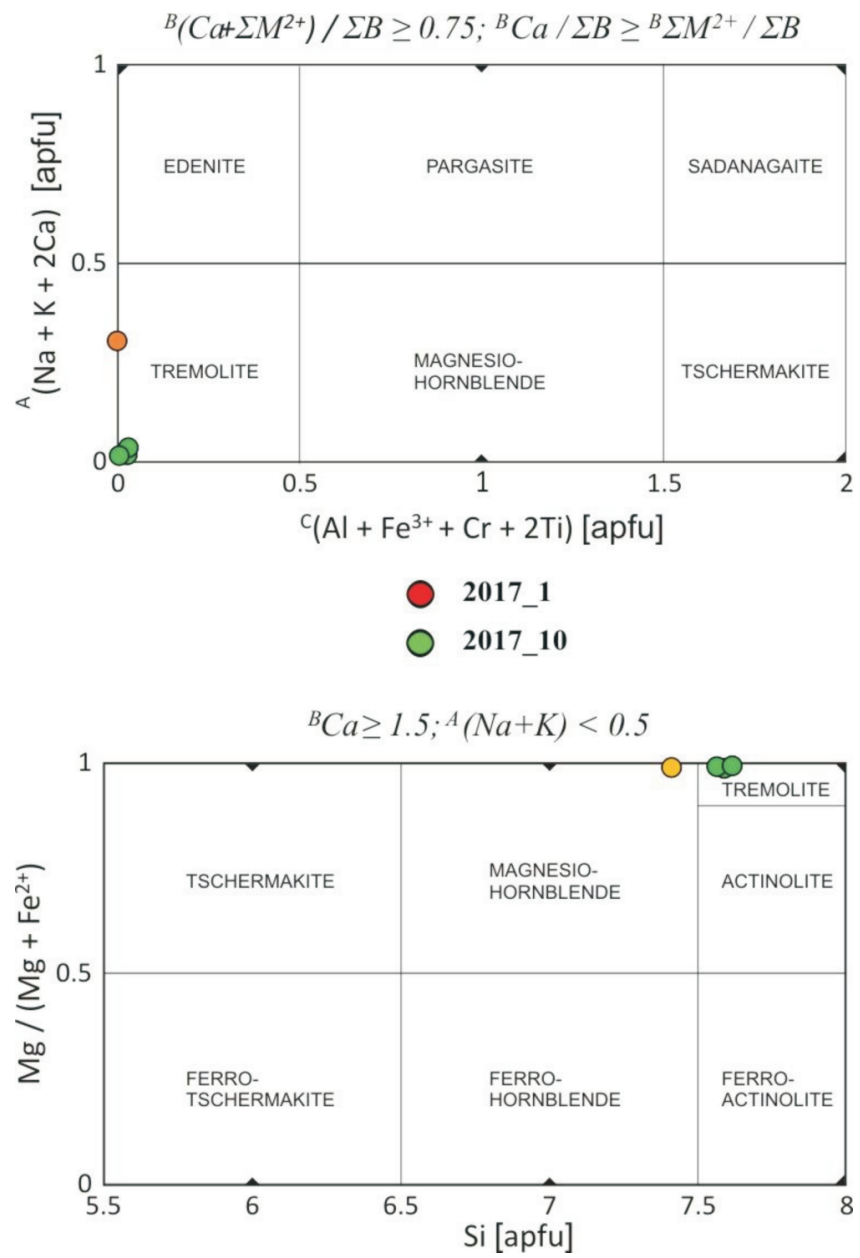

Fig. 10. Classification of amphibole from marble samples from the Bílý Kámen Hill and from archaeological artefact from Stará Kouřim $(2017$ 10) in the diagrams according to Leake et al. (1977) and Hawthorne et al. (2012)
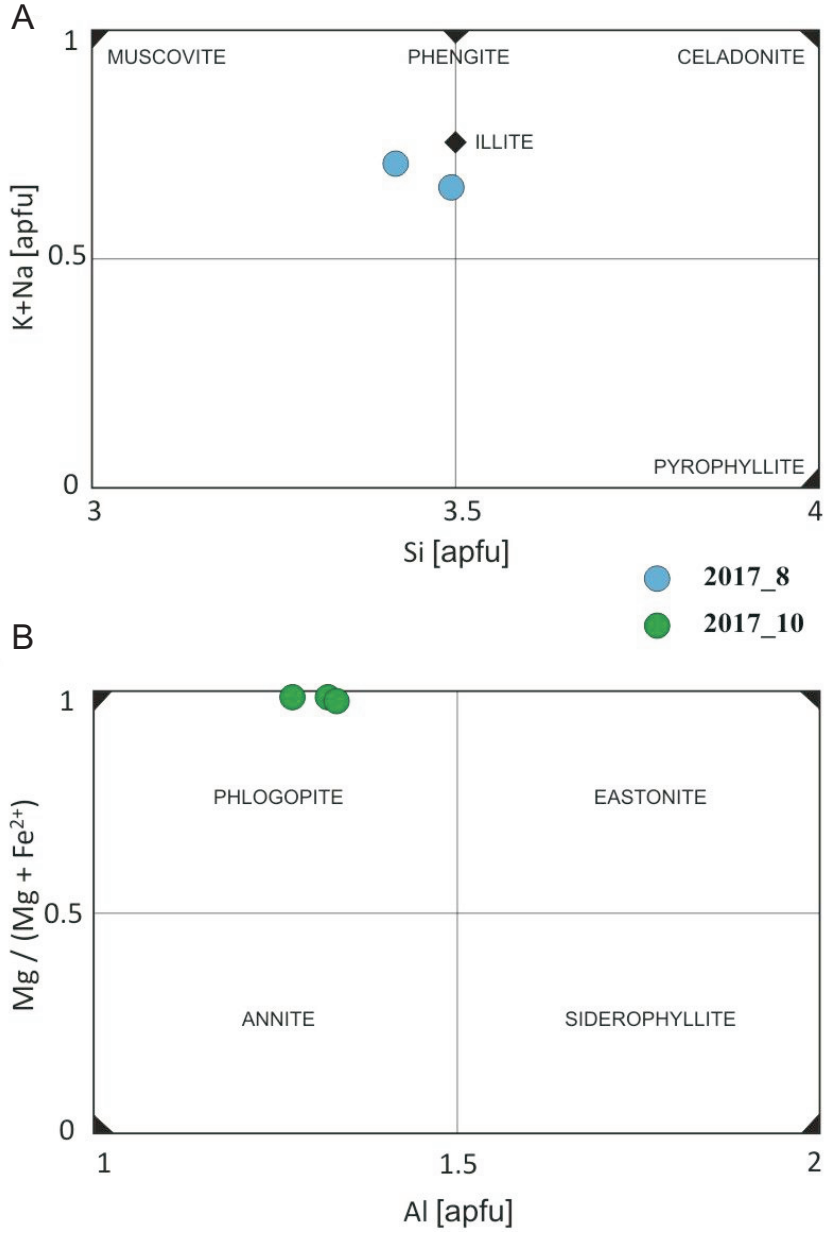

Fig. 11. Classification of muscovite from marble Bílý Kámen 2017_8 (A) and of dark mica from marble artefact Stará Koưrim 2017_10 (B) according to Deer et al. (1992)

\section{SILICATES}

The most common accessory minerals are amphiboles, both in marble Bílý Kámen 2017_1 and archaeological sample Stará Kouřim 2017 10. They usually form subhedral crystals up to $0.3 \mathrm{~mm}$ in size, more or less replaced by chlorite. Dolomitic marble Stará Kourim 2017_10 contains fairly pure tremolite (Fig. 10, in terms of the classification of Leake et al., 1977 or Hawthorne et al., 2012) with only a small amount of $\mathrm{Na}$ (up to $0.09 \mathrm{apfu}$ ), $\mathrm{Al}$ (up to $0.44 \mathrm{apfu}$ ), $\mathrm{Fe}^{2+}$ (up to $0.06 \mathrm{apfu}$ ) and traces of $\mathrm{K}$ (up to $0.03 \mathrm{apfu}$ ), $\mathrm{Ti}$ (up to $0.01 \mathrm{apfu}$ ) and $\mathrm{Cl}$. The fluorine content is also low (up to $0.20 \mathrm{apfu}$ ). Sporadic amphiboles from sample 2017_1 are very similar in composition. Dark mica, forming tabular crystals up to $0.3 \mathrm{~mm}$ in size, is present only in archaeological sample 2017_10. Commonly, the crystals are rimmed or partly replaced by chlorite (Fig. 12C). Its composition corresponds to phlogopite (Fig. 11B) with an eastonite component content being between 14 and $17 \mathrm{~mol} \%$. The presence of an annite or siderophyllite component is negligible due to the very low content of $\mathrm{Fe}$ (up to $0.66 \mathrm{wt}$ \% FeO; Table 1 ). The contents of other elements are very low ( $\mathrm{Na}$ up to 0.04 apfu, Ba up 
Chemical composition (main oxides, trace elements, rare earth elements) of eight marble samples from Bílý Kámen and,

\begin{tabular}{|c|c|c|c|c|c|c|c|c|c|c|c|c|c|c|c|c|c|c|c|c|c|}
\hline \multicolumn{2}{|c|}{ Sample } & $\mathrm{SiO}_{2}$ & $\mathrm{Al}_{2} \mathrm{O}_{3}$ & $\mathrm{Fe}_{2} \mathrm{O}_{3}$ & $\mathrm{MgO}$ & $\mathrm{CaO}$ & $\mathrm{Na}_{2} \mathrm{O}$ & $\mathrm{K}_{2} \mathrm{O}$ & $\mathrm{TiO}_{2}$ & $\mathrm{P}_{2} \mathrm{O}_{5}$ & $\mathrm{MnO}$ & LOI & Sum & $\mathrm{Ba}$ & Co & Cs & $\mathrm{Nb}$ & $\mathrm{Rb}$ & $\mathrm{Sr}$ & Th & $U$ \\
\hline & Unit & \multicolumn{12}{|c|}{ [\%] } & \multicolumn{8}{|c|}{ ppm } \\
\hline $\begin{array}{c}\text { Bílý } \\
\text { Kámen } \\
2017 \_1\end{array}$ & $\begin{array}{l}\text { Rock } \\
\text { Pulp }\end{array}$ & 1.63 & 0.26 & 0.15 & 0.74 & 54.60 & 0.04 & 0.02 & $<0.01$ & 0.02 & 0.02 & 42.5 & 99.98 & 52 & 0.3 & $<0.1$ & 0.4 & 0.3 & 213.1 & $<0.2$ & 0.1 \\
\hline $\begin{array}{c}\text { Búlý } \\
\text { Kámen } \\
2017 \_2\end{array}$ & $\begin{array}{l}\text { Rock } \\
\text { Pulp }\end{array}$ & 3.14 & 0.21 & 0.16 & 0.42 & 53.39 & 0.04 & 0.02 & $<0.01$ & 0.14 & 0.03 & 42.4 & 99.95 & 16 & $<0.2$ & $<0.1$ & 0.1 & 0.5 & \begin{tabular}{|l|}
197.9 \\
\end{tabular} & $<0.2$ & 0.3 \\
\hline $\begin{array}{c}\text { Bílý } \\
\text { Kámen } \\
2017 \_3\end{array}$ & $\begin{array}{l}\text { Rock } \\
\text { Pulp }\end{array}$ & 1.13 & 0.07 & 0.11 & 0.36 & 55.13 & $<0.01$ & $<0.01$ & $<0.01$ & 0.04 & 0.03 & 43.1 & 99.97 & 3 & $<0.2$ & $<0.1$ & 0.3 & $<0.1$ & \begin{tabular}{|l|}
198.2 \\
\end{tabular} & $<0.2$ & 0.2 \\
\hline $\begin{array}{c}\text { Bílý } \\
\text { Kámen } \\
2017 \_4\end{array}$ & $\begin{array}{l}\text { Rock } \\
\text { Pulp }\end{array}$ & 2.55 & 0.15 & 0.19 & 0.79 & 53.78 & $<0.01$ & $<0.01$ & $<0.01$ & 0.02 & 0.02 & 42.4 & 99.90 & 66 & $<0.2$ & $<0.1$ & $<0.1$ & $<0.1$ & 217.7 & $<0.2$ & 0.1 \\
\hline $\begin{array}{c}\text { Búlý } \\
\text { Kámen } \\
2017 \_5\end{array}$ & $\begin{array}{l}\text { Rock } \\
\text { Pulp }\end{array}$ & 4.06 & 0.14 & 0.15 & 0.65 & 53.02 & $<0.01$ & $<0.01$ & $<0.01$ & 0.20 & 0.05 & 41.7 & 99.97 & 7 & $<0.2$ & $<0.1$ & $<0.1$ & $<0.1$ & 216.5 & $<0.2$ & 0.2 \\
\hline $\begin{array}{c}\text { Bílý } \\
\text { Kámen } \\
2017 \_6\end{array}$ & $\begin{array}{l}\text { Rock } \\
\text { Pulp }\end{array}$ & 1.62 & 0.15 & 0.16 & 0.67 & 54.32 & $<0.01$ & $<0.01$ & 0.01 & $<0.01$ & 0.02 & 43.0 & 99.95 & 8 & $<0.2$ & $<0.1$ & $<0.1$ & $<0.1$ & 283.6 & $<0.2$ & 0.1 \\
\hline $\begin{array}{c}\text { Bílý } \\
\text { Kámen } \\
2017 \_7\end{array}$ & $\begin{array}{l}\text { Rock } \\
\text { Pulp }\end{array}$ & 2.29 & 0.11 & 0.19 & 0.76 & 53.68 & $<0.01$ & $<0.01$ & $<0.01$ & 0.06 & 0.04 & 42.8 & 99.93 & 9 & 0.2 & $<0.1$ & $<0.1$ & $<0.1$ & 212.3 & 0.2 & $<0.1$ \\
\hline $\begin{array}{c}\text { Bílý } \\
\text { Kámen } \\
2017 \_8\end{array}$ & $\begin{array}{l}\text { Rock } \\
\text { Pulp }\end{array}$ & 3.32 & 0.22 & 0.24 & 0.58 & 53.41 & $<0.01$ & 0.02 & $<0.01$ & 0.03 & 0.02 & 42.1 & 99.94 & 10 & 0.2 & 0.7 & 0.3 & 2.7 & 298.5 & 0.4 & 0.2 \\
\hline $\begin{array}{c}\text { Stará } \\
\text { Kourüim } \\
\text { 2017_10 }\end{array}$ & $\begin{array}{l}\text { Rock } \\
\text { Pulp }\end{array}$ & 2.76 & 0.35 & 0.44 & 19.11 & 32.42 & $<0.01$ & 0.08 & 0.03 & 0.01 & 0.05 & 44.4 & 99.65 & 14 & 0.9 & $<0.1$ & 0.1 & 1.9 & \begin{tabular}{|l|}
112.8 \\
\end{tabular} & 0.5 & 0.4 \\
\hline
\end{tabular}

In addition, the following elements with values below the limit of detection were also determined: $\mathrm{Ni}<20 \mathrm{ppm}, \mathrm{Sc}<1 \mathrm{ppm}, \mathrm{Be}<1 \mathrm{ppm}, \mathrm{Ga}<0.5 \mathrm{ppm}$, analysis performed by the Bureau Veritas Commodities Canada Ltd.

to 0.01 apfu, Ca up to 0.01 apfu, and $V$ up to $0.01 \mathrm{apfu})$. The exception is $\mathrm{Ti}$, the content of which fluctuates between 0.06 and 0.07 apfu (1.05-1.36 wt.\% $\mathrm{TiO}_{2}$ ). The fluorine content is relatively low and ranges between 0.30 and 0.34 apfu. Lower potassium content (0.64-0.69 apfu) in most of analyses and partial non-stoichiometry suggests weak chloritization of phlogopite in places.

Muscovite, rich in the phengitic component, was identified only in samples Bílý Kámen 2017_3 and 2017_8. It forms aggregates, up to $0.3 \mathrm{~mm}$ in size, composed of flaky crystals often associated with phyllosilicate from the smectite group and quartz (Fig. 12D). The celadonite component varies around 40 mol.\% (Fig. 11A). The reduced occupancy of the A-position (i.e. the lower $\mathrm{K}+\mathrm{Na}$ content) also indicates an elevated proportion of the pyrophyllite component. The increased $\mathrm{Ca}$ content ( $\sim 0.06 \mathrm{apfu})$ is unusual, but this may be related to submicroscopic inclusions of carbonates (Table 1).

Chlorite was observed replacing or rimming amphibole and phlogopite, or intergrowing with talc only in archaeological sample 2017_10 (Fig. 12C). The chemical composition is close to clinochlorite with a low amount of $\mathrm{Fe}$ (up to 0.07 apfu or 0.89 wt.\% FeO; Table 1).
Talc that was identified only in archaeological sample 2017_10 intimately intergrowts with chlorite, calcite and small grains of unidentified Ti-oxide (Fig. 12C). Its chemical composition corresponds to relatively pure end member, with only traces of $\mathrm{Al}$ (up to $0.02 \mathrm{apfu}$ ) and Fe (up to $0.02 \mathrm{apfu}$ ). Traces of $\mathrm{Ca}$ (up to $0.01 \mathrm{apfu}$ ) could relate to the submicroscopic presence of carbonates

\section{APATITE}

Apatite was found in all samples often as isometric isolated grains ranging in size between 50 and $150 \mu \mathrm{m}$. In sample 2017_3, it occurs obviously near irregular suture-like contacts produced by pressure dissolution (stylolites) and filled with a phyllosilicate of the smectite group (Fig. 12A). The apatite corresponds to almost pure fluorapatite in all cases. Only a trace amount of $\mathrm{Cl}$ was found in samples 2017_1 and 2017_8 (up to 0.01 apfu), and a slightly elevated content in marble 2017_10 (up to 0.08 apfu) (Table 1). Based on the conversion stechiometry, the highest hydroxylapatite component content was in sample 2017_1 (5-10 mol\%), while it did not exceed $5 \mathrm{~mol} \%$ in the other samples. Sample 
for comparison, one archaeological sample (drilling core) from the SBK workshop at Stará Kouřim

\begin{tabular}{|c|c|c|c|c|c|c|c|c|c|c|c|c|c|c|c|c|c|c|c|c|c|c|c|}
\hline Sample & $\mathrm{Zr}$ & $Y$ & $\mathrm{La}$ & $\mathrm{Ce}$ & $\mathrm{Pr}$ & $\mathrm{Nd}$ & $\mathrm{Sm}$ & $\mathrm{Eu}$ & $\mathrm{Gd}$ & $\mathrm{Tb}$ & Dy & $\mathrm{Ho}$ & $\mathrm{Er}$ & $\mathrm{Tm}$ & $\mathrm{Yb}$ & $\mathrm{Lu}$ & Mo & $\mathrm{Cu}$ & $\mathrm{Pb}$ & $\mathrm{Zn}$ & $\mathrm{Ni}$ & As & $\mathrm{Cd}$ \\
\hline & \multicolumn{23}{|c|}{ ppm } \\
\hline $\begin{array}{c}\text { Bílý } \\
\text { Kámen } \\
2017 \_1\end{array}$ & 2.6 & 0.4 & 0.7 & 1.1 & 0.12 & 0.5 & 0.07 & 0.02 & 0.11 & 0.02 & 0.08 & $<0.02$ & 0.04 & $<0.01$ & 0.07 & $<0.01$ & 0.5 & 1.2 & 3.7 & 10 & $<0.1$ & 0.6 & $<0.1$ \\
\hline $\begin{array}{c}\text { Bílý } \\
\text { Kámen } \\
2017 \_2\end{array}$ & 2.7 & 2.4 & 2.0 & 2.4 & 0.38 & 1.4 & 0.27 & 0.10 & 0.39 & 0.05 & 0.27 & 0.06 & 0.17 & 0.02 & 0.12 & 0.02 & 0.7 & 1.1 & 6.5 & 18 & 0.1 & $<0.5$ & 0.2 \\
\hline $\begin{array}{c}\text { Bílý } \\
\text { Kámen } \\
2017 \_3\end{array}$ & 4.6 & 2.1 & 2.0 & 2.2 & 0.34 & 1.5 & 0.26 & 0.08 & 0.32 & 0.05 & 0.29 & 0.06 & 0.12 & 0.02 & 0.11 & 0.02 & 0.3 & 2.1 & 3.8 & 6 & $<0.1$ & $<0.5$ & 0.3 \\
\hline $\begin{array}{c}\text { Bílý } \\
\text { Kámen } \\
2017 \_4\end{array}$ & 2.0 & 0.5 & 0.9 & 1.0 & 0.14 & 0.4 & 0.05 & 0.02 & 0.11 & 0.01 & $<0.05$ & $<0.02$ & 0.04 & $<0.01$ & $<0.05$ & $<0.01$ & 0.4 & 1.1 & 3.6 & 12 & 0.4 & 0.7 & $<0.1$ \\
\hline $\begin{array}{c}\text { Bílý } \\
\text { Kámen } \\
2017 \_5\end{array}$ & 2.8 & 2.4 & 2.0 & 2.3 & 0.31 & 1.3 & 0.24 & 0.07 & 0.26 & 0.04 & 0.24 & 0.05 & 0.09 & 0.01 & 0.08 & 0.01 & 0.3 & 1.6 & 2.4 & 7 & $<0.1$ & 0.6 & $<0.1$ \\
\hline $\begin{array}{c}\text { Bílý } \\
\text { Kámen } \\
2017 \_6\end{array}$ & 3.1 & 0.7 & 1.3 & 1.8 & 0.21 & 0.8 & 0.16 & 0.04 & 0.13 & 0.02 & 0.12 & $<0.02$ & 0.07 & $<0.01$ & $<0.05$ & $<0.01$ & 0.5 & 1.0 & 3.1 & 11 & 0.7 & 0.8 & $<0.1$ \\
\hline $\begin{array}{c}\text { Bílý } \\
\text { Kámen } \\
2017 \_7\end{array}$ & 1.5 & 4.2 & 1.8 & 2.8 & 0.38 & 1.3 & 0.49 & 0.13 & 0.67 & $\mid$\begin{tabular}{|l|l}
$\mid$ \\
$\mid$
\end{tabular} & 0.74 & 0.13 & 0.40 & 0.04 & 0.23 & 0.05 & 0.4 & 0.9 & 7.0 & 5 & 0.8 & 0.5 & $<0.1$ \\
\hline $\begin{array}{c}\text { Bílý } \\
\text { Kámen } \\
2017 \_8\end{array}$ & 2.8 & 1.0 & 2.7 & 3.4 & 0.30 & 1.0 & 0.11 & 0.05 & 0.15 & 0.02 & 0.14 & 0.03 & 0.08 & $\varangle 0.01$ & 0.08 & 0.01 & 1.0 & 1.3 & 4.2 & 8 & 0.3 & 2.2 & $<0.1$ \\
\hline $\begin{array}{c}\text { Stará } \\
\text { Koururim } \\
2017 \_10\end{array}$ & 15.0 & 1.3 & 2.2 & 2.8 & 0.33 & 1.2 & 0.23 & 0.06 & 0.23 & 0.03 & 0.17 & 0.03 & 0.10 & 0.01 & 0.13 & 0.02 & 1.6 & 1.7 & 3.9 & 37 & 0.9 & $<0.05$ & 0.1 \\
\hline
\end{tabular}

$\mathrm{Hf}<0.1 \mathrm{ppm}, \mathrm{Sn}<1 \mathrm{ppm}, \mathrm{Ta}<0.1 \mathrm{ppm}, \mathrm{V}<8 \mathrm{ppm}, \mathrm{Bi}<0.1 \mathrm{ppm}, \mathrm{Ag}<0.1 \mathrm{ppm}, \mathrm{Au}<0.5 \mathrm{ppb}, \mathrm{W}<0.5 \mathrm{ppm}, \mathrm{Tl}<0.1 \mathrm{ppm}, \mathrm{Sb}<0.1 \mathrm{ppm}, \mathrm{Hg}<0.01 \mathrm{ppm}$;

2017 10 yielded a trace content of $\mathrm{S}$ up to $0.007 \mathrm{apfu}$, and all samples show a trace content of $\mathrm{Si}(\sim 0.01 \mathrm{apfu})$. The contents of other elements were below the detection limit.

\section{OTHER ACCESSORIES}

A grain of Ca-rich plagioclase, up to $0.1 \mathrm{~mm}$ large, was found in sample Bílý Kámen 2017_1. The content of anorthite component exceeds $95 \mathrm{~mol} \%$. It is associated with a tiny crack filled with barite. In archaeological sample 2017_10, Ti-oxides (predominantly rutile), $50 \mu \mathrm{m}$ in size, were identified as inclusions in chlorite-talc intergrowths (Fig. 12C). Limonite pseudomorphs after probably pyrite represent other substantially less frequent accessory minerals in sample 2017_1.

Our findings are largely in line with the earlier petrographic studies of Koutek (1936) and Kachlík (1999) suggesting that the marble from Bílý Kámen is pure calcite marble with the accessory presence of silicates (tremolite, muscovite, chlorite) and apatite. This type is exceptional in the Šternberk-Čáslav Group. Dolomitic marbles dominate there (for example the nearby bodies at Český Šternberk). While crystalline limestones are also widespread in southern Moldanubicum, these contain diopside and other minerals that do not occur in marble from the Bílý Kámen Hill, such as titanite, allanite and, more rarely (in the Český Krumlov belt of the Varied Moldanubian Group), tourmaline (Houzar et al., 2017).

\section{CHEMICAL COMPOSITION}

Complete chemical analysis of eight marble samples was implemented in the laboratories of Bureau Veritas Minerals (Vancouver, Canada). As shown in Table 1, there are no significant differences in their composition; the whole body is therefore homogeneous. In all cases these are very pure calcite marbles with an average of only $\sim 0.62 \%(0.36-0.79 \%) \mathrm{MgO}$ and a minimum of other major oxides: $\mathrm{SiO}_{2}$ on average $2.47 \%$ (1.63-4.06\%), $\mathrm{Al}_{2} \mathrm{O}_{3}$ on average $0.16 \%(0.07-0.26 \%)$, total $\mathrm{Fe}$ expressed as $\mathrm{Fe}_{2} \mathrm{O}_{3}$ on average $0.17 \%(0.11-0.24 \%)$ and $\mathrm{P}_{2} \mathrm{O}_{5}$ on average $0.06 \%(0.01-0.20 \%)$. Other oxides, i.e. $\mathrm{TiO}_{2}$, $\mathrm{Na}_{2} \mathrm{O}, \mathrm{K}_{2} \mathrm{O}$ and $\mathrm{MnO}$, did not reach even $0.05 \%$. The quantities of the majority of other trace elements $(\mathrm{Ag}, \mathrm{Au}, \mathrm{Cr}, \mathrm{Hg}, \mathrm{Ni}, \mathrm{Sc}$, $\mathrm{Be}, \mathrm{Bi}, \mathrm{Cd}, \mathrm{Co}, \mathrm{Cs}, \mathrm{Ga}, \mathrm{Hf}, \mathrm{Sb}, \mathrm{Se}, \mathrm{Sn}, \mathrm{Ta}, \mathrm{Th}, \mathrm{TI}, \mathrm{V}, \mathrm{W}$ ) were below or at the limit of sensitivity of the methods used. None of 

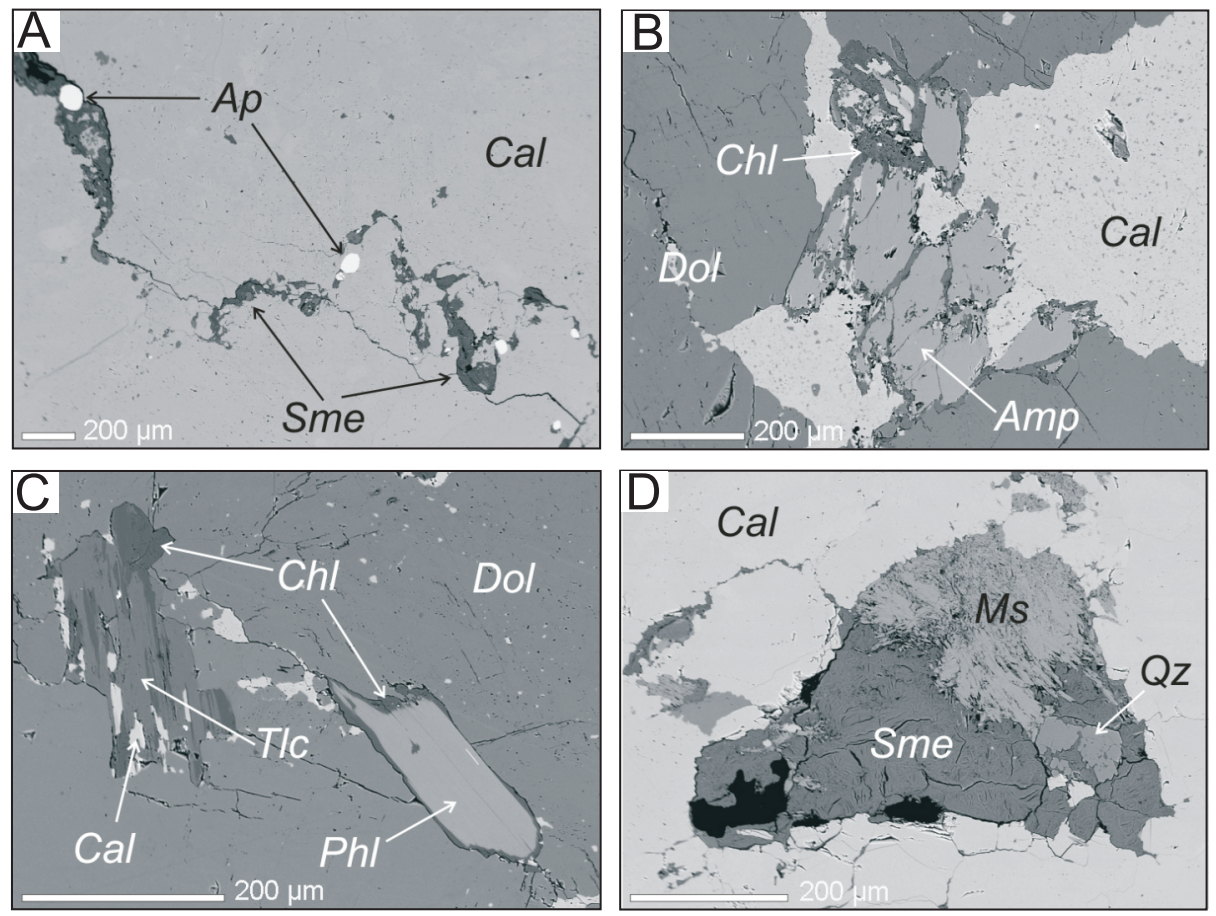

Fig. 12. Back-scattered images of individual accessory minerals in marble Bílý Kámen 2017_3 (A, D) and marble artefact 2017_10 (B, C)

For explanations see the text

the samples from the Bílý Kámen Hill could be classified as dolomitic marble or dolomite.

For comparison, we also analysed a few marble artefacts from nearby prehistoric workshops in the Kouřim area using the ED-XRF method. All artefacts showed substantially different composition as concerns the $\mathrm{MgO}$ content. It means they are represented by dolomitic marbles. To be sure, we also prepared one of these artefacts for a precise analysis in the laboratories of Bureau Veritas Minerals. It was a marble drilling core from Stará Kouřim (Table 1, Sample 2017 10). We could use only one artefact because the analyses in Canada are destructive. At first glance, there are obvious differences in its chemistry compared to the marble samples from the Bílý Kámen Hill. The main ones concerned the higher content of $\mathrm{MgO}$ (mineralogically dolomite) and $\mathrm{Al}_{2} \mathrm{O}_{3}$. The total $\mathrm{Fe}$, expressed as $\mathrm{Fe}_{2} \mathrm{O}_{3}$, is also higher. As regards the trace elements, it is necessary to emphasize the significantly increased $\mathrm{Zn}$ and $\mathrm{Zr}$ contents, while radioactive elements $U$ and $T h$ are present in slightly higher contents. It is therefore obvious that yet another source of marble (in this case dolomitic) must have been used during the Neolithic period. This could be in the area of the Sternberk-Čáslav Group of the Kutná Hora Crystalline Complex, for example somewhere in the vicinity of Český Šternberk. Similar findings of marble artefacts come from the work of Březinová and Bukovanská (1984), as part of their petrographic assessment connected with the research of Zápotocká (1984). According to examination of the results of colouring tests and X-ray diffractography, they also suggested that the raw material used for making the drilling cores from Stará Kourim and the Kolín area was highly dolomitic limestones to metadolomites. They sought their sources in the bodies of dolomitic marble in the area between Český Šternberk, Malovidy and Soběšín.

\section{DENSITY}

This property seems to be very important because it can be determined by non-destructive method. We found significant differences between densities of calcite marble from the Bilý Kámen Hill and that of artefact (drilling core) from Stará Kouřim. Densities of the pure calcite marble from prehistoric quarries vary between $2.678-2.697 \mathrm{~g} / \mathrm{cm}^{3}$, while density of the drilling core from Stará Kouřim is substantially higher $-2.826 \mathrm{~g} / \mathrm{cm}^{3}$ and is very similar to densities of dolomitic marble from other potential source - the abandoned quarry "Na Střibrné" near Český Šternberk: $2.838-2.859 \mathrm{~g} / \mathrm{cm}^{3}$.

\section{CONCLUSIONS}

Prehistoric quarries discovered in 1937 on the Bílý Kámen Hill near Sázava represent the first proof of Neolithic extraction of non-siliceous raw material in continental Europe. The aim of this work is to characterize comprehensively the raw material extracted. It is a high-grade, white-to-grey calcite marble with an admixture of $\mathrm{SiO}_{2}$ up to $4 \%$ and $\mathrm{MgO}$ up to $1 \%$. Other oxides are $<0.3 \%$. The marble forms a lens $\sim 850 \mathrm{~m}$ long and up to $200 \mathrm{~m}$ wide in the biotite and sillimanite-biotite paragneiss of the Šternberk-Čáslav Group (southern part of the Kutná Hora crystalline unit). Several granite veins from the nearby Central Bohemian pluton penetrate the marble in several places, and it is also disturbed by a NNE-SSW-running fault system. Thin-sections clearly show marble mylonitization due to pressure-texture disturbance. The calcite itself contains only a small amount of $\mathrm{Mg}$ and Fe. Silicate minerals are represented by rare occur- 
rences of amphibole, muscovite and a phyllosilicate like smectite. Among heavy minerals, there is a significant presence of small apatite grains in the surroundings of stylolites, and of Ti-oxide (probably rutile), while ore minerals are represented by pseudomorphs of goethite after pyrite.

Due to the proven Neolithic extraction, the marble from the Bílý Kámen Hill near Sázava is considered by archaeologists (Zápotocká, 1984) as the source of raw materials not only for the bracelets but also for other marble personal ornaments in central Bohemia, the cemeteries of the Rössen culture near Halle in east Germany, and in other places. The marble bracelets (or drilling cores that document their production) found in the workshops of the Stroked Pottery culture in the nearby Kourim and Kolín areas were assumed to be marble from the Bílý Kámen Hill. ED-XRF analyses of more marble artefacts, including a detailed chemical analysis of the drilling core from Stará Kouřim (archaeological sample 2017_10, dolomitic marble) given in this paper, does not, however, correspond to the pure calcite marble from the Bilý Kámen Hill. There are also differences in occurrences of accessory minerals (almost pure tremolite, dark mica corresponding to phlogopite, and presence of talc have been recorded in the dolomitic marble of archaeological sample).

A similar conclusion about the different raw material of artefacts (dolomitic marble to metadolomite) compared with the crystalline limestone from the Bílý Kámen Hill had already been reached earlier by $\mathrm{D}$. Březinová and M. Bukovanská, using colouring tests and X-ray diffraction (Zápotocká, 1984). On the other hand, the striking proximity of these workshops to the sources of marbles and dolomitic marbles between Sázava and Český Šternberk suggests that some other bodies in the vicinity of Český Šternberk were also probably exploited. The systematic archaeological and geological exploration of this area in the coming years, supported by the Czech Science Foundation, should resolve these questions.

Our findings are largely in line with the earlier petrographic studies of Koutek (1936) and Kachlík (1999) suggesting that the occurrence at the Bílý Kámen Hill is pure calcite marble with rare accessory silicates (amphibole, muscovite, smectite-like mica) and apatite. This type is exceptional in the Šternberk-Čáslav Group; dolomitic marble dominates there (e.g., the nearby bodies near Český Šternberk). While marbles are also widespread in southern Moldanubicum, these contain diopside and other minerals that do not occur in marble from the Bilý Kámen Hill, such as titanite and allanite, and, more rarely (in the Český Krumlov belt of the Varied Moldanubian Group) also tourmaline (Houzar et al., 2017).

Acknowledgements. The research described in this paper was accomplished with support from the project "Marble as a raw material in the Neolithic jewels of Central Europe" (Project 19-04121S), financed by the Czech Science Foundation. The authors are grateful to the journal referees for their critical reviews of the manuscript.

\section{REFERENCES}

Březinová, D., Bukovanská, M. 1984. Petrographische Expertise über das Material der Armringe und Bohrkerne. Památky Archeologické, 75: 131-132.

Deer, W. A., Howie, R.A., Zussman, J., 1992. An Introduction to the Rock Forming Minerals. 2nd edition. Longman Scientific and Technical, New York.

Hawthorne, F.C., Oberti, R., Harlow, G.E., Maresch, W.V., Martin, R.F., Schumacher, J.C., Welch, M.D., 2012. IMA report. Nomenclature of the amphibole supergroup. American Mineralogist, 97: 2031-2048.

Houzar, S., Novák, M., Cícha, J. 2017. Přehled minerálních asociací a litologie mramorů české části moldanubika (Český masiv) (in Czech). Bulletin Mineralogicko-petrografického Oddělení Národního Muzea v Praze, 25: 113-140.

Kachlík, V. 1999. Relationship between Moldanubicum, the Kutná Hora Crystalline Unit and Bohemicum (Central Bohemia, Czech Republic): a result of the polyphase Variscan nappe tectonics. Journal of the Czech Geological Society, 44: 201-291

Kodym, O. ed., 1997. Geologická mapa ČR. List 13-33 Benešov (in Czech). Český geologický Ústav. Praha.

Koutek, J., 1936. Ložisko krystalického vápence v Sázavě $n$. Sázavou (in Czech). Věstník Státního Geologického Ústavu Československé Republiky, 12: 61-67.

Leake, B.E., Wooley, A.R., Arps, C.E.S., Birch, W.D., Gilbert, M.C., Grice, J.D., Hawthorne, F.C., Kato, A., Kisch, H.J., Krivovichev, V.G., Linthout, K., Laird, J., Mandarino, J., Maresch, W.V., Nickel, E.H., Schumacher, J.C., Smith, D.C., Stephenson, N.C.N., Ungaretti, L., Whittaker, E.J.W., Youzhi, G. 1997. Nomenclature of amphiboles. Report of the Subcommittee on Amphiboles of the International Mineralogical Association Commission on New Minerals and Mineral Names. European Journal of Mineralogy, 9: 623-651.
Merlet, C., 1994. An accurate computer correction program for quantitative electron probe microanalyses. Microchimica Acta, 114/115: 363-376.

Munsell rock-colors chart, 1995. Geological Society of America, 8th printing.

Niquet, F., 1937. Die Rössener Kultur in Mitteldeuschland. Jahreschrift Halle, 26: 1-111

Šída, P., Kachlík, V., Prostředník, J., 2014. Neolitická těžba metabazitů v Jizerských horách (in Czech). Opomíjená archeologie (3). Katedra archeologie Filozofické fakulty Západočeské univerzity, Plzeň.

Šrein, V., Šreinová, B., Sejkora, J., Š astný, M., Kolman, B. 2007. Mineralogická charakteristika metasomatického rudního ložiska Malovidy u Českého Šternberka (in Czech). Bulletin Mineralogicko-petrologického Oddělení Národního Muzea v Praze, 14-15: 149-158.

Vencl, S., 1960. Kamenné nástroje prvních zemědělců ve střední Evropě (in Czech). Acta Musei Nationalis Pragae, 14/A: 1-91.

Vencl, S., 1971. Pravěké lomy „Bílý kámen“. Sázava, okr. Kutná Hora (in Czech). Mapa 1:500. Kartografie Praha.

Whitney, D.L., Evans, B.E. 2010. Abbreviations for names of rock-forming minerals. American Mineralogist, 95: 185-187.

Zápotocká, M., 1984. Armringe aus Marmor und anderen Rohstoffen im jüngeren Neolithikum Böhmens und Mitteleuropas. Památky archeologické, 75: 50-132.

Žebera, K., 1939. Archeologický výzkum Posázaví. Neolitické a středověké vápencové lomy na "Bílém kameni“ u Sázavy (in Czech). Památky archeologické, 41: 51-58.

Žebera, K., 1955. Nerostné suroviny v kamenných dobách pravěku (in Czech). In: Přehledné Dějiny Československého Hornictví (ed. J. Kořan): 8-53. Nakladatelství Československé akademie věd, Praha. 